\title{
Evaluation of different strategies to produce biofuels from Nannochloropsis oculata and Chlorella vulgaris
}

\author{
M.P. Caporgno ${ }^{\text {a }}$, M. Olkiewicz ${ }^{\text {a }}$, A. Fortuny ${ }^{\mathrm{b}}$, F. Stüber ${ }^{\mathrm{a}}$, A. Fabregat ${ }^{\mathrm{a}}$, J. Font ${ }^{\mathrm{a}}$, J. Pruvost ${ }^{\mathrm{c}}$, O. Lepine ${ }^{\mathrm{d}}$, \\ J. Legrand ${ }^{\mathrm{c}}, \mathrm{C}$. Bengoa ${ }^{\mathrm{a}, *}$ \\ a Departament d'Enginyeria Química, Universitat Rovira i Virgili, Av. Països Catalans 26, 43007 Tarragona, Spain \\ b Departament d'Enginyeria Química, Universitat Politècnica de Catalunya, Av. Víctor Balaguer S/N, 08800 Vilanova i la Geltrú, Spain \\ c GEPEA, Université de Nantes, CNRS, UMR6144, bd de l'Université, CRTT - BP 406, 44602 Saint-Nazaire Cedex, France \\ d AlgoSource SAS, 37 bd de l'Université, CRTT - BP 406, 44602 Saint-Nazaire Cedex, France
}

\begin{abstract}
A B S T R A C T
The lipid extraction using hexane and methanol:hexane increased the biodegradability of Nannochloropsis oculata by $36 \%$ and $24 \%$ respectively. Moreover, hexane increased the methane production from raw microalgae, from $253 \pm 11$ to $313 \pm 9 \mathrm{~mL}_{\mathrm{CH}_{4}} / \mathrm{g}_{\mathrm{vs}}$. Methanol:hexane did not affect the methane production, which yielded $254 \pm 10 \mathrm{~mL}_{\mathrm{CH} 4} / \mathrm{g}_{\mathrm{vs}}$, mainly due to the significant changes in the biomass composition.

On the other hand, the lipid extraction failed to increase the biodegradability of Chlorella vulgaris, which resulted around $44 \%$ for raw and lipid-extracted microalgae. The methane productions were $219 \pm 6,202 \pm 1$ and $200 \pm$

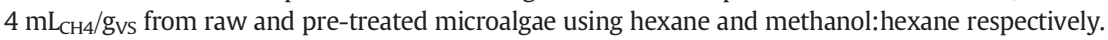

Regarding the lipid extraction yields, using methanol:hexane the yields were 4.7 and 3.7 times higher for $N$. oculata and $C$. vulgaris than using hexane. The biodiesel yields were also higher using methanol:hexane, 2.4 and 1.9 times than using hexane. However, the biodiesel composition was unaffected by the solvent.

The substrate to inoculum ratio influenced raw $N$. oculata digestion. At 1:1 $\mathrm{VS}_{\text {Substrate }}: \mathrm{VS}_{\text {Inoculum, }}$, the methane production throughout the first days decreased but not the ultimate methane production. $C$. vulgaris digestion was unaffected, probably due to the biomass characteristics.

Finally, the co-digestion of microalgae and sewage sludge showed no synergy, nor inhibition.
\end{abstract}

\section{Introduction}

Microalgae present extraordinary characteristics for producing renewable biofuels, such as high biomass productivity and accumulation of lipids amongst some others [1,2]. The genus Nannochloropsis and Chlorella are examples of promising microalgae for biodiesel and methane production [3-6]. Biodiesel has high biodegradability, low toxicity, low emission profile, and does not need major modification in engines and refuelling technology [7]; however, the biodiesel from microalgae presents economical and sustainable limitations. There are considerable efforts underway to achieve favourable energy balances and production costs, for example, trying to find cost-effective and efficient lipid extraction technologies [1]. Processes using ionic liquids [7] or wet extraction can reduce the high costs of harvesting and drying [8,9], but they are not large-scale processes yet. Methane is an alternative to biodiesel. The anaerobic digestion $(\mathrm{AD})$ or methanisation is ideal for processing wet biomass, reducing the cost derived from microalgae drying. This wellknown technology, widely used with manures, municipal organic

\footnotetext{
* Corresponding author.

E-mail address: christophe.bengoa@urv.cat (C. Bengoa).
}

solid waste and sewage sludge, has gained more attention for processing microalgae in recent years $[2,6]$. Another driving force behind AD is the possibility of recycling nutrients for microalgae cultivation; microalgae can uptake nutrients from the aqueous phase recovered after digestion $[5,10,11]$.

In spite of the differences, biodiesel and methane production can be complementary. The organic solvents can break the cell walls during the lipid extraction from microalgae [12,13], acting as a pre-treatment before $\mathrm{AD}$. The lipid extraction also mitigates the inhibitory effect of high concentration of lipid on $\mathrm{AD}$ [14]. Hexane is one of the solvents commonly used in the commercial extraction of edible lipid, and in the extraction of omega-3 LC-PUFA from microalgae [15]; it is inexpensive and offers high efficiency and suitability for industrial processes [1]. High extraction yields have been reported using polar solvents or mixtures, but most of the mixtures contain halogenated solvents considered carcinogenic [15]. Methanol:hexane (2:3 v:v) proved to be one of the best non-halogenated polar mixtures for the lipid extraction from of Nannochloropsis sp. [16]. After the extraction, the AD of the microalgae generates methane which can be use for electricity and/or heat in the biodiesel production [2]. An increasing number of publications recently appeared showing the benefits of coupling both processes [17]. 
The anaerobic co-digestion (Aco-D) of microalgae is another favourable option to convert microalgae into methane, mainly due to the unbalanced $\mathrm{C}$ to $\mathrm{N}$ ratio $(\mathrm{C}: \mathrm{N})$ in microalgae $[2,6,18,19]$. Unlike $A D$, the co-digestion processes mixtures of substrates, resulting in a more favourable C:N. The sewage sludge is one of the most widely used cosubstrates; it is generated in wastewater treatment plants (WWTP), available in large quantities and suitable for AD. The over-sized digesters in WWTP promote the utilisation of sewage sludge in codigestion as well [20]. Sewage sludge has been co-digested with some microalgae species [21-23], but no results were reported using Nannochloropsis.

The present study considers various strategies to produce methane from Nannochloropsis and Chlorella species. Firstly, the influence of the substrate to inoculum ratio (SIR) on $A D$ was evaluated for both microalgae species. The SIR markedly affects the performance of the digesters, depending on the species and characteristics of microalgae [12, 14,24]. The next experiments were performed applying the lipid extraction as pre-treatment to improve $A D$, using hexane and methanol:hexane $(2: 3 \mathrm{v}: \mathrm{v})$. The lipids recovered from the pretreatment were converted into biodiesel, and the influence of solvents was evaluated. Finally, the last strategy consisted in the co-digestion of microalgae and sewage sludge.

\section{Materials and methods}

\subsection{Materials}

\subsubsection{Microalgae, inoculum and sewage sludge}

Nannochloropsis oculata and Chlorella vulgaris were provided by AlgoSource's (Alpha Biotech, Asserac, France). N. oculata was received as frozen slurry with $28 \%$ total solids, thus stored at $-15{ }^{\circ} \mathrm{C}$ until required. C. vulgaris was received dried, thus stored in a dessicator. Both microalgae are hereinafter referred to as "raw" biomass.

The inoculum utilised in AD experiments consisted of digested sludge obtained from a mesophilic pilot-plant $\left(33^{\circ} \mathrm{C}\right)$ under semicontinuous operating conditions. Prior to setting the experiments, the inoculum was "degassed" as described in Caporgno et al. [23]. The sewage sludge utilised for feeding the pilot-plant and the batch digesters in co-digestion consisted of a primary and secondarysludge blend $(65: 35 v / v)$, collected from the municipal WWTPs in Reus (Tarragona, Spain). This blend is representative of the sludge generated in the WWTPs.

\subsection{Experimental procedure}

\subsubsection{Pre-treatment with organic solvents: lipid extraction}

Before the pre-treatment, $N$. oculata was freeze-dried (FT33-A Freeze Drier, Armfield Inc.); C. vulgaris drying was unnecessary. For the pre-treatment, $2 \mathrm{~g}$ of dried microalgae were extracted in a Soxhlet apparatus with a reflux period of $7 \mathrm{~h}$. Hexane and methanol:hexane ( $2: 3 \mathrm{v}: \mathrm{v})$ were utilised as solvents. The recovered lipids were converted into biodiesel, identified and quantified according to the procedure described by Olkiewicz et al. [25]. The pre-treated microalgae were anaerobically digested. Prior to AD, the biomass was left unstoppered in a hood for several hours until complete evaporation of the remaining solvent.

\subsubsection{Anaerobic digestion experiments}

Batch reactors were set up at $33{ }^{\circ} \mathrm{C}$ following the procedure described by Angelidaki and Sanders for the determination of methane potential [26]. The substrates differed in the experiments. The microalgae samples were re-suspended in deionised water before digestion, resulting in a solid concentration similar to sewage sludge.

The SIR experiments were performed using only raw microalgae as substrates. The SIRs were set at 1:4, 1:2 and $1: 1 \mathrm{VS}_{\text {Substrate }}: \mathrm{VS}_{\text {Inoculum }}$ where VS is the volatile solid content in substrates and inoculum.
The effects of the pre-treatment were evaluated using pre-treated and raw microalgae. Since $N$. oculata was freeze-dried before the pretreatment, the possible effects of the drying process were evaluated using freeze-dried microalgae. The SIR was 1:2 $\mathrm{VS}_{\text {Substrate }}: \mathrm{VS}_{\text {Inoculum }}$ in all reactors.

Co-digestion was performed using mixtures of raw N. oculata and sewage sludge. The mixtures contained $25 \%, 50 \%$ and $75 \%$ sewage sludge on a VS basis. The SIR was 1:2 VS $\mathrm{S}_{\text {Substrate }}: \mathrm{VS}_{\text {Inoculum }}$ in all reactors.

\subsection{Analytical techniques}

\subsubsection{Substrate characterisation}

Total solids (TS), volatile solids (VS) and chemical oxygen demand (COD) were analysed according to standard methods 2540B, 2540E and 5220D respectively [27]. Protein, carbohydrate and lipid content in raw and pre-treated biomass were quantified as described in [23]. The characteristics of the inoculum and the substrates are summarised in Table 1. The TS and COD values for raw microalgae correspond to the microalgae suspensions in deionised water used in the experiments.

Raw and pre-treated microalgae samples were analysed by Fourier Transform Infrared (FTIR) spectroscopy using a Fourier Jasco FT/IR600 Plus spectrometer with a diamond golden gate ATR (GS10542, Specac Ltd) reflectance cell.

\subsubsection{Products characterisation}

The biogas production and its composition, and the volatile fatty acid concentration (VFA) were measured following the procedure described in [23]. The ammonia concentration was determined with an ion selective electrode (Ammonia Gas Sensing combination electrode, mod. 51927-00, HACH).

The first order hydrolysis model [26] was used for hydrolysis rate calculation, Eq. (1):

$\ln \frac{B_{0}-B}{B_{0}}=-k_{h} \cdot t$

where $\mathrm{B}$ is the cumulative methane yield at the time $\mathrm{t}$ (units: $\mathrm{mL}_{\mathrm{CH} 4}$ / $\left.\mathrm{g}_{\mathrm{vs}}\right), \mathrm{k}_{\mathrm{h}}\left(\right.$ days $\left.^{-1}\right)$ is the first order hydrolysis constant and $\mathrm{B}_{0}\left(\mathrm{~mL}_{\mathrm{CH} 4} /\right.$ $\mathrm{g}_{\mathrm{vs}}$ ) is the ultimate methane production. The values of $\mathrm{k}_{\mathrm{h}}$ and $\mathrm{B}_{0}$ were determined in MS Excel 2007® using the Solver tool, by minimising the residual sum of squared errors between the experimental data and the data predicted by the model.

The theoretical methane potential was calculated based on the relative fractions of lipid, protein and carbohydrate in the substrates, and assuming the specific methane yields of $1014 \mathrm{~mL}_{\mathrm{CH} 4} / \mathrm{g}_{\mathrm{VS}}, 496 \mathrm{~mL} \mathrm{CH}_{4} / \mathrm{g}_{\mathrm{VS}}$, $415 \mathrm{~mL}_{\mathrm{CH} 4} / \mathrm{g}_{\mathrm{vs}}$ for lipid, protein and carbohydrate respectively [26]. The biodegradability was then calculated considering the measured and the theoretical methane production, Eq. (2):

Biodegradability $(\%)=\frac{\text { measured methane production }}{\text { theoretical methane potential }} \times 100$.

Microalgae cells before and recovered after AD were observed under light microscope to evaluate the integrity of the cells (ZEISS Axio Scope.A1, with ProgRes ${ }^{\circledR}$ SpeedXT core 3 camera).

\section{Results and discussion}

\subsection{The influence of the SIR on anaerobic digestion}

The influence of the SIR on AD was evaluated in order to determine the most suitable SIR for the experiments. The ultimate methane productions and the $\mathrm{k}_{\mathrm{h}}$ for $N$. ocualta and $C$. vulgaris are listed in Table 2 .

The SIR did not affect the ultimate methane production from N. oculata and C. vulgaris; the differences were smaller than $3 \%$ in the experiments using the same microalgae species. On the contrary, the $\mathrm{k}_{\mathrm{h}}$ 
Table 1

Characteristics of the inoculum and the substrates used in the anaerobic digestion experiments.

\begin{tabular}{|c|c|c|c|c|c|c|c|c|}
\hline \multirow[t]{2}{*}{ Parameter } & \multirow[t]{2}{*}{ Inoculum } & \multirow[t]{2}{*}{ Sludge } & \multicolumn{3}{|c|}{ Nannochloropsis oculata } & \multicolumn{3}{|c|}{ Chlorella vulgaris } \\
\hline & & & $\operatorname{Raw}^{(a)}$ & $\operatorname{Hex}^{(\mathrm{b})}$ & Met:Hex ${ }^{(c)}$ & $\operatorname{Raw}^{(\mathrm{a})}$ & $\operatorname{Hex}^{(\mathrm{b})}$ & Met:Hex ${ }^{(c)}$ \\
\hline $\mathrm{TS}(\mathrm{g} / \mathrm{L})$ & $14.8 \pm 0.1$ & $33.2 \pm 0.1$ & $37.0 \pm 0.0$ & - & - & $32.8 \pm 0.4$ & - & - \\
\hline $\mathrm{VS} / \mathrm{TS}$ & 0.63 & 0.83 & 0.90 & 0.88 & 0.88 & 0.81 & 0.76 & 0.74 \\
\hline $\mathrm{COD}\left(\mathrm{mg} \mathrm{O}_{2} / \mathrm{L}\right)$ & $13600 \pm 280$ & $42000 \pm 400$ & $51000 \pm 900$ & - & - & $35500 \pm 300$ & - & - \\
\hline $\mathrm{C}: \mathrm{N}$ & - & 13.88 & 5.36 & - & - & 7.44 & - & - \\
\hline Proteins (g/100g $\left.g_{v s}\right)$ & - & - & $60.9 \pm 3.4$ & $67.6 \pm 4.9$ & $85.9 \pm 2.1$ & $48.7 \pm 4.0$ & $49.6 \pm 1.5$ & $73.8 \pm 3.3$ \\
\hline Lipids (g/100g $\left.g_{v s}\right)$ & - & - & $21.9 \pm 0.4$ & 13.8 & - & $6.5 \pm 0.6$ & 3.4 & - \\
\hline Carbohydrates (g/100g $\mathrm{g}_{\mathrm{vs}}$ ) & - & - & $16.7 \pm 1.5$ & $18.7 \pm 1.8$ & $14.1 \pm 2.2$ & $41.2 \pm 0.7$ & $42.5 \pm 1.5$ & $26.2 \pm 2.4$ \\
\hline
\end{tabular}

a Suspension in deionised water.

b Pre-treated using hexane.

c Pre-treated using methanol:hexane.

was affected differently by the SIR for both microalgae. For N. oculata, the hydrolysis rate accelerated when the SIR increased from $1: 4$ to $1: 2$ but it slowed down when the SIR increased until 1:1. The $\mathrm{k}_{\mathrm{h}}$ depends on the methane production throughout the first days of the experiment, and the SIR can considerably influence the methane production during these days $[12,14,24]$. The substrate concentration abruptly increased from low concentration in the "degassed" inoculum to high concentration after setting up the reactors at SIR 1:1, which caused a stress response in bacteria. The $\mathrm{k}_{\mathrm{h}}$ suggests that VFA accumulated and were not efficiently converted into methane. The methane yields at the end of the experiment indicated that the VFA accumulation did not cause inhibition because of the possibility of bacteria to adapt to different environmental conditions over time [2]. However, SIR higher than 1:1, could lead to higher VFA concentration and inhibition of the process. $N$. oculata was characterised by high protein content (Table 1 ), which can cause inhibition by ammonia [2]; inhibition by ammonia was dismissed based on its concentration at the end of the experiment. Regarding $C$. vulgaris, the $\mathrm{k}_{\mathrm{h}}$ was unaffected by the SIR. The presence of aggregates in $C$. vulgaris reduced the interaction between microorganisms and microalgae, thus the amount of substrates readily available for microorganisms was lower than in the reactors with $N$. oculata. The SIR threshold which affects AD depends on the microalgae and their characteristics [12,14,24].

Microalgae were observed under a light microscope before and after digestion. Fig. 1a shows N. oculata after thawing. Microalgae cells with a similar appearance were recovered from digestate at the end of the experiment (Fig. 1b). Regarding C. vulgaris, Fig. 1c reveals the presence of microalgae aggregates before digestion. The aggregates originated during microalgae drying were also visible after digestion (Fig. 1d). The resistance of several Chlorella species to anaerobic digestion and the presence of intact cells after AD were reported by others [28]. Chlorella species presents stronger cell walls than Nannochloropsis, requiring powerful pre-treatment to enhance the biodegradability [3]. Furthermore, C. vulgaris aggregates may hamper the interaction with microorganisms.

The $\mathrm{pH}$ at the end of the experiments was close to neutrality, ranging 7.35-7.68. Ammonia concentration ranged $677-836 \mathrm{mg} / \mathrm{L}$, whereas $1500 \mathrm{mg} / \mathrm{L}$ is considered as threshold for inhibition [2]. Inhibition during

Table 2

Ultimate methane productions and $\mathrm{k}_{\mathrm{h}}$ during $\mathrm{AD}$ of $\mathrm{N}$. oculata and $C$. vulgaris at different SIR.

\begin{tabular}{|c|c|c|c|c|c|}
\hline & & & \multicolumn{3}{|l|}{ SIR } \\
\hline & & & $1: 4$ & $1: 2$ & $1: 1$ \\
\hline \multirow[t]{2}{*}{ Substrate } & N. oculata & $\begin{array}{l}\mathrm{CH}_{4} \mathrm{~mL}_{\mathrm{CH} 4} / \mathrm{g}_{\mathrm{Vs}} \\
\mathrm{k}_{\mathrm{h}}^{(\mathrm{a})}\left(\text { days }^{-1}\right)\end{array}$ & $\begin{array}{l}278 \pm 3 \\
0.31 \\
(0.91)\end{array}$ & $\begin{array}{l}275 \pm 4 \\
0.35 \\
(0.93)\end{array}$ & $\begin{array}{l}282 \pm 9 \\
0.19 \\
(0.99)\end{array}$ \\
\hline & C. vulgaris & $\begin{array}{l}\mathrm{CH}_{4} \mathrm{~mL}_{\mathrm{CH} 4} / \mathrm{g}_{\mathrm{vs}} \\
\mathrm{k}_{\mathrm{h}}^{(\mathrm{a})}\left(\text { days }^{-1}\right)\end{array}$ & $\begin{array}{l}229 \pm 12 \\
0.36 \\
(0.98)\end{array}$ & $\begin{array}{l}223 \pm 4 \\
0.36 \\
(0.99)\end{array}$ & $\begin{array}{l}222 \pm 3 \\
0.37 \\
(0.71)\end{array}$ \\
\hline
\end{tabular}

\footnotetext{
a In brackets, the values of $\mathrm{R}^{2}$
}

$\mathrm{AD}$ results in VFA accumulation and decrease in $\mathrm{pH}$ [2]; however, the concentrations of VFA were under the detectable limit of the analysis, indicating no signs of inhibition. Biogas composition was analysed periodically and the methane content was between $71 \%-74 \%$; there was not a relationship between the methane content and the substrate or the SIR.

The results indicate that the SIR is important parameter in anaerobic digestion and its effects over anaerobic digestion depend on the substrate characteristics. For the AD of microalgae, the SIR evaluation may prevent anaerobic digestion failure mainly due to the high protein content. Based on the results, the SIR 1:2 VS $\mathrm{S}_{\text {Substrate }}: \mathrm{VS}_{\text {Inoculum }}$ was decided for all the experiments. The presence of $C$. vulgaris aggregates suggested the need of pre-treatment before $\mathrm{AD}$, thus the microalgae was not used in the Aco-D experiments.

\subsection{Microalgae pre-treatment and biodiesel production}

Lipid extraction and biodiesel production yields are presented in Table 3. The main purpose of the lipid extraction was the microalgae pre-treatment; although the lipids were converted into biodiesel, the feasibility of biodiesel production was not evaluated in the present studio. The microalgae obtained after the pre-treatment may represent the waste generated in a wide variety of processes employing organic solvents. The pre-treatment may offer additional advantages if highvalue by-products are obtained.

The highest lipid extraction yields were obtained using the polar mixture. From $N$. oculata, the lipid extractions yielded $48.1 \pm 2.6$ and $10.1 \pm 0.4 \mathrm{~g} / 100 \mathrm{~g}_{\mathrm{vs}}$ using methanol:hexane and hexane respectively; from $C$. vulgaris, $17.6 \pm 0.2$ and $4.7 \pm 0.9 \mathrm{~g} / 100 \mathrm{~g}_{\mathrm{vs}}$ respectively. The polar mixture led to the highest biodiesel yields as well; biodiesel increased from $5.0 \pm 0.1$ to $12.6 \pm 0.2$ and $\mathrm{g} / 100 \mathrm{~g}_{\mathrm{vs}}$ in $\mathrm{N}$. oculata and from $2.4 \pm 0.1$ to $4.5 \pm 0.1 \mathrm{~g} / 100 \mathrm{~g}_{\mathrm{vs}}$ in $C$. vulgaris using the polar mixture. It is widely known that polar solvents or their mixtures lead to higher extraction yields than the non-polar ones. Polar solvents extract polar lipids such as phospholipids and glycolipids [14-16] and also polar components such as proteins and carbohydrates; these latter are not lipid but increase the lipid extraction yield significantly [29]. Since the major part of these polar components fails transesterification, the biodiesel yield was not as high as expected based on the lipid extraction yields (Table 2). Fig. 2 shows the spectra obtained during FTIR analyses of raw and pre-treated $N$. oculata. The spectrum after the extraction using hexane confirms the reduction in the lipid content; the absorption bands at $1700-1750 \mathrm{~cm}^{-1}$ characteristics of $C=0$ groups in lipid esters and the absorption bands at 2,800-3,000 $\mathrm{cm}^{-1}$ characteristics of $\mathrm{CH}_{2}$ and $\mathrm{CH}_{3}$ groups in lipid acyl chains [30] are less intensified than in raw microalgae spectrum. These absorption bands are much lower intensified in the spectrum after the extraction using methanol:hexane.

On the other hand, the biodiesel composition was unaffected by the solvents. The biodiesel profile for $N$. oculata showed high content of C16:0, C16:1 and C20:5 using both solvents. A similar profile was reported by Balasubramanian et al. using the same polar mixture [16]. 


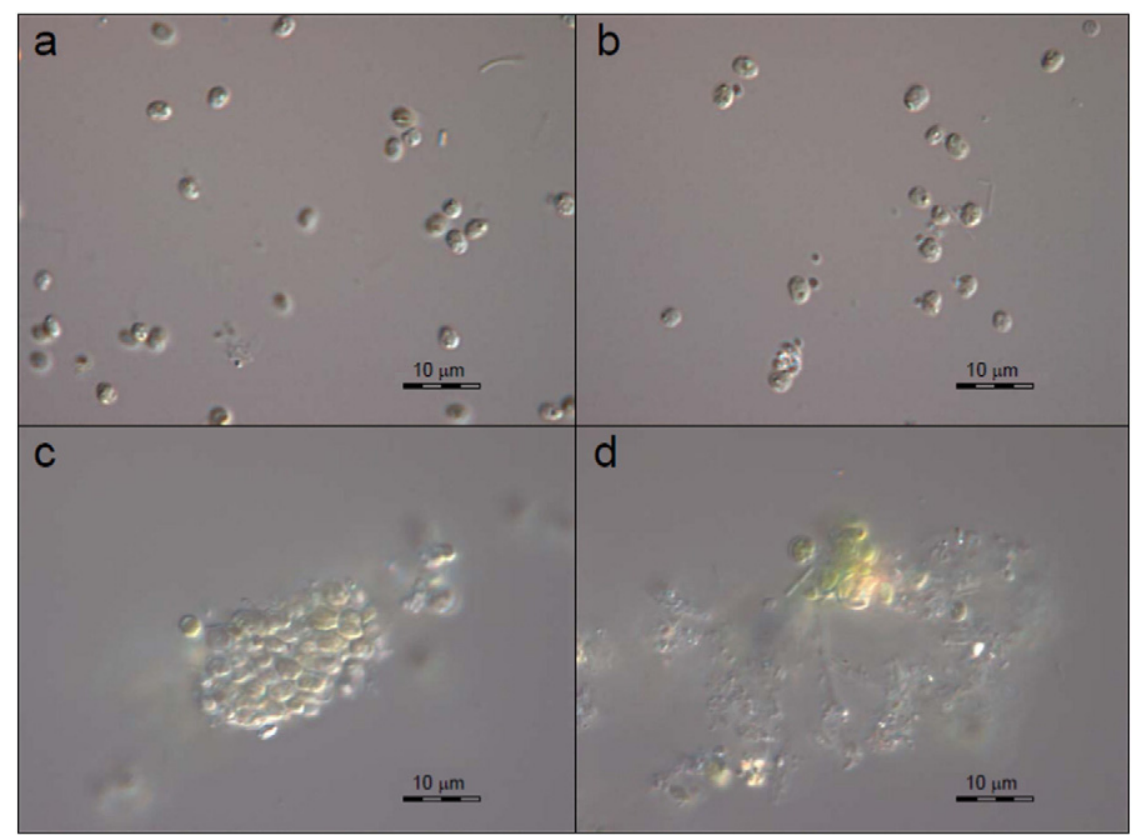

Fig. 1. Light micrographs of raw N. oculata (a) and recovered from the digestate (b), and raw C. vulgaris (c) and recovered from the digestate (d).

These fatty acids were also the most predominant in the biodiesel produced from the same microalgae species using ionic liquids [7]. Regarding the profile for $C$. vulgaris, it was similar to the profile reported for the biodiesel from vegetable oils [31]; C16:0, C18:0, C18:1, C18:2 and C18:3 were predominant in C. vulgaris, as reported by other authors [32]. When comparing the biodiesel from both microalgae species, the main difference lies in the high content of the polyunsaturated fatty acid C20:5 in N. oculata. The C20:5 is associated with a decrease in the oxidative stability of the biodiesel [7].

\subsection{Anaerobic digestion of pre-treated microalgae}

\subsubsection{Nannochloropsis oculata}

The methane production curves from raw and pre-treated $N$. oculata are presented in Fig. 3a. It stands out the curve obtained from the microalgae pre-treated using hexane; the methane yield was considerably higher than the yield obtained from raw microalgae. The ultimate methane production from the raw $N$. oculata was $253 \pm 11 \mathrm{~mL}_{\mathrm{CH} 4} / \mathrm{g}_{\mathrm{vs}}$, similar to the value reported in the literature [2]. The pre-treatment with hexane increased the methane production until $313 \pm 9 \mathrm{~mL}_{\mathrm{CH} 4} / \mathrm{g}_{\mathrm{vs}}$; whereas the polar mixture seemed not to influence the methane production.
The biodegradability depends on both the theoretical and the measured methane production (Eq. (2)), being the theoretical methane calculated from the substrates composition. The theoretical methane production significantly decreased in pre-treated microalgae; the lipid content decreased and they almost double proteins and carbohydrates in terms of theoretical methane production. However, the measured methane production from pre-treated microalgae was similar or higher than from raw microalgae. As a consequence, the biodegradability resulted in $57 \%$ and $52 \%$ for the pre-treated microalgae using hexane and the polar mixture respectively, higher than the $42 \%$ calculated for raw microalgae. Hexane degraded some compounds present in the microalgae or disrupted the cell walls, resulting in higher methane production and enhanced biodegradability [13]. The high extraction yields with polar solvents entailed significant changes in the biomass composition which affect the methane production $[14,29]$. These changes in composition may hide the disruption caused by the solvents; the biodegradability increased but the methane production decreased compared with raw microalgae [14].

The $\mathrm{k}_{\mathrm{h}}$ was calculated (Eq. (1)) for the different substrates. It resulted in 0.40 day $^{-1}\left(R^{2}=0.97\right)$ for raw microalgae, and 0.31 day $^{-1}\left(R^{2}=\right.$ $0.99)$ and 0.21 day $^{-1}\left(R^{2}=0.99\right)$ for the pre-treated microalgae using hexane and methanol:hexane respectively. These values indicated that

Table 3

Lipid extraction yields, biodiesel yields and fatty acids composition.

\begin{tabular}{|c|c|c|c|c|}
\hline \multirow[t]{2}{*}{ Fatty acids } & \multicolumn{2}{|c|}{ Nannochloropsis oculata } & \multicolumn{2}{|c|}{ Chlorella vulgaris } \\
\hline & Hex & Met:Hex & Hex & Met:Hex \\
\hline Lipid extraction yield (g/100g $\left.g_{v s}\right)$ & $10.1 \pm 0.4$ & $48.1 \pm 2.6$ & $4.7 \pm 0.9$ & $17.6 \pm 0.2$ \\
\hline Biodiesel yield ( $\left.\mathrm{g} / 100 \mathrm{~g}_{\mathrm{vs}}\right)$ & $5.0 \pm 0.1$ & $12.6 \pm 0.2$ & $2.4 \pm 0.1$ & $4.5 \pm 0.1$ \\
\hline \multicolumn{5}{|l|}{ Biodiesel composition $\left(\mathrm{g} / 100 \mathrm{~g}_{\text {sample }}\right)$} \\
\hline Myristic (C14:0) & $3.7 \pm 0.1$ & $4.1 \pm 0.1$ & $0.2 \pm 0.1$ & - \\
\hline Palmitic (C16:0) & $6.6 \pm 0.1$ & $14.3 \pm 0.1$ & $21.9 \pm 0.2$ & $24.2 \pm 0.2$ \\
\hline cis-9 Palmitoleic (C16:1) & $19.8 \pm 0.2$ & $25.0 \pm 0.1$ & $9.2 \pm 1.0$ & $12.1 \pm 0.1$ \\
\hline Cis-10-heptadecenoic (C17:1) & - & - & $12.1 \pm 0.1$ & $10.4 \pm 0.1$ \\
\hline Oleic (C18:1) & $1.9 \pm 0.1$ & $2.0 \pm 0.1$ & $8.3 \pm 0.1$ & $8.1 \pm 0.1$ \\
\hline Linoleic (C18:2) & $1.3 \pm 0.1$ & $1.4 \pm 0.1$ & $8.2 \pm 0.1$ & $8.2 \pm 0.1$ \\
\hline Linolenic (C18:3) & $0.9 \pm 0.1$ & $1.0 \pm 0.1$ & $26.2 \pm 0.1$ & $24.1 \pm 0.1$ \\
\hline cis-11,14-Eicosadienoic (20:2) & $3.2 \pm 0.1$ & $3.4 \pm 0.1$ & - & - \\
\hline cis-5,8,11,14-Eicosatetraenoic (20:4) & $5.2 \pm 0.1$ & $3.9 \pm 0.1$ & - & - \\
\hline cis-5,8,11,14,17-Eicosapentaenoic (20:5) & $49.9 \pm 0.1$ & $38.7 \pm 0.4$ & - & - \\
\hline Others & $7.6 \pm 0.1$ & $6.1 \pm 0.1$ & $13.0 \pm 0.1$ & $13.8 \pm 0.1$ \\
\hline
\end{tabular}




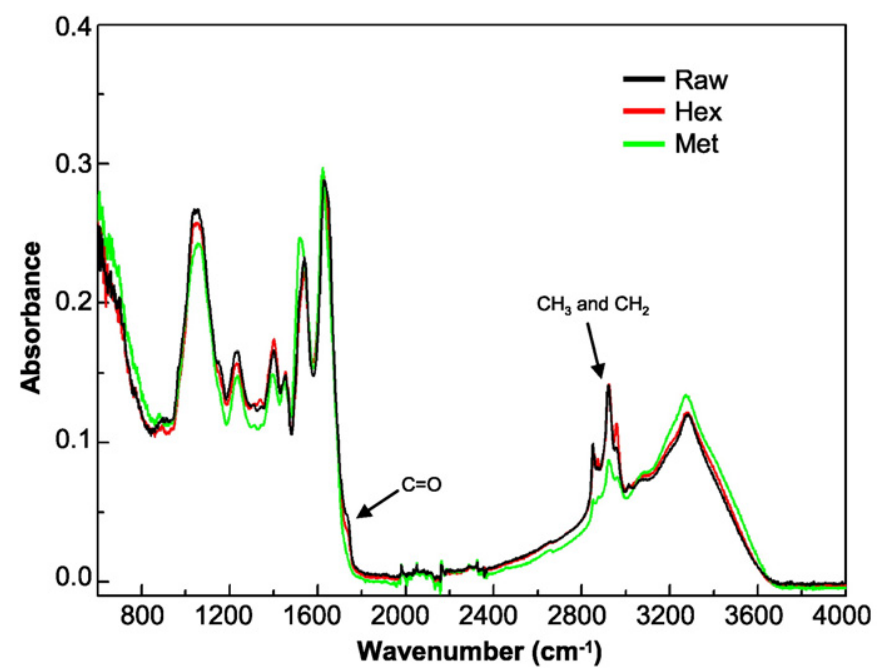

Fig. 2. FTIR spectra of raw N. oculata (raw) and pre-treated, using hexane (Hex) and methanol-hexane (Met).

the pre-treatment decreased the methane production throughout the first days of the experiment. However, all reactors had exceeded $80 \%$ of the ultimate methane production by the 8th day, thus most of the substrate was degraded at that time. Since the same SIR was set in all the reactors, the decrease in $\mathrm{k}_{\mathrm{h}}$ can not be attributed to a stress response
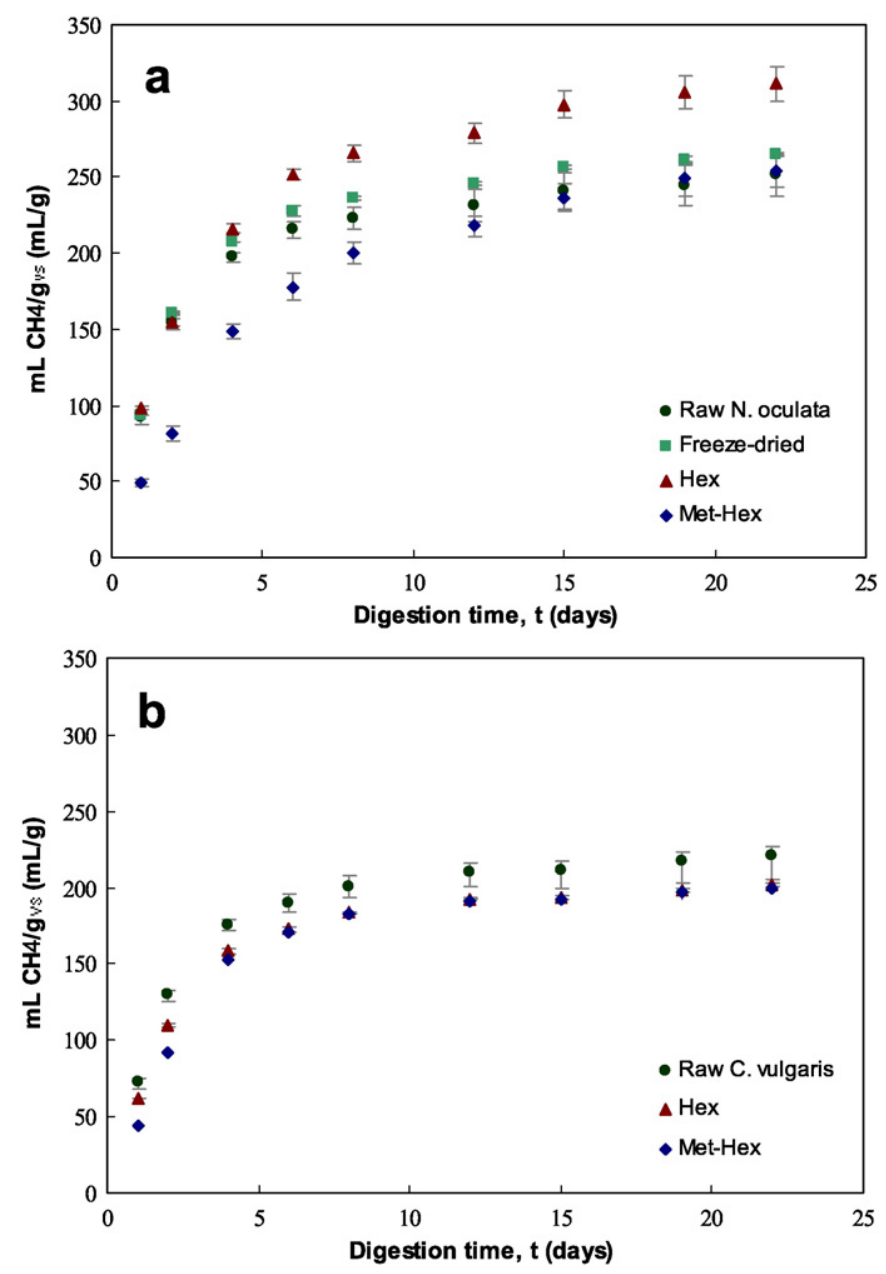

Fig. 3. The methane production curves from a) N. oculata and b) C. vulgaris. Symbols: - raw, $\boldsymbol{\square}$ freeze-dried and pre-treated, using $\boldsymbol{\Delta}$ hexane and $\bullet$ methanol-hexane. Batch reactors at $33{ }^{\circ} \mathrm{C}$ and SIR of $1: 2 \mathrm{VS}_{\text {Substrate }}: \mathrm{VS}_{\text {Inoculum. }}$ as it was explained in Section 3.1. In this case, the values indicated that raw microalgae were easily digested than pre-treated ones. Different compounds were extracted in the pre-treatment, thus different compounds remained in the pre-treated microalgae. Possibly the pretreatment extracted some easily-degradable components or it changed the characteristics of some of them, resulting in slow degradation.

Regarding the effects of drying, the methane production yielded $265 \pm 3 \mathrm{~mL}_{\mathrm{CH} 4} / \mathrm{g}_{\mathrm{vs}}$ after freeze-drying. The methane production curve was similar to the curve for raw microalgae (Fig. 2a), which indicated the absence of adverse effects. Adverse effects are mainly attributed to microalgae heating in the drying process [22,33], but heating was avoided during $N$. oculata drying.

The $\mathrm{pH}$, ammonia and VFA concentrations at the end of the experiments confirmed that all digesters operated at optimum conditions. The digesters exhibited no signs of inhibition in spite of the solvent utilisation; the presence of residual organic solvents can entail the failure of the digester [14,29,34]. Periodical analysis of the biogas composition revealed that the methane content was between $70 \%$ and $73 \%$ in all reactors.

\subsubsection{Chlorella vulgaris}

The methane production curves from raw and pre-treated $C$. vulgaris are presented in Fig. 3b. The methane production yielded $219 \pm 6$ $\mathrm{mL}_{\mathrm{CH} 4} / \mathrm{g}_{\mathrm{Vs}}$ from raw microalgae and decreased around $8-9 \%$ after the pre-treatment. Contrary to N. oculata, both solvents negatively affected the methane production from $C$. vulgaris. The theoretical methane production barely decreased after the pre-treatment due to the low lipid content in raw $C$. vulgaris (Table 1); thus the biodegradability resulted in $44 \%$ for raw microalgae and $42 \%$ for the pre-treated microalgae. The analysis of $\mathrm{k}_{\mathrm{h}}$ confirmed that the pre-treatment does not accelerate the digestion of microalgae; $k_{h}$ were 0.39 day $^{-1}\left(R^{2}=0.99\right)$ for raw microalgae, and 0.36 day $^{-1}\left(R^{2}=0.99\right)$ and 0.32 day $^{-1}\left(R^{2}=0.99\right)$ for the microalgae pre-treated using hexane and methanol:hexane respectively. As observed during $N$. ocualta AD, part of the easilydegradable components may be extracted during the pre-treatment, decreasing $\mathrm{k}_{\mathrm{h}}$.

The analysis performed at the end of the experiment confirmed that all digesters operated at optimum conditions and exhibited no signs of inhibition. The biogas composition ranged between $69 \%$ and $74 \% \mathrm{CH}_{4}$ in all reactors.

\subsection{Anaerobic co-digestion of microalgae and sewage sludge}

The Aco-D of $N$. oculata and sewage sludge was evaluated as an option to improve AD. Fig. 4 shows the methane production curves from $N$. oculata, sewage sludge and their mixtures.

The sewage sludge and the microalgae produced the highest and the lowest methane yields respectively. The mixtures showed yields between these extremes. In fact, the methane production from the mixtures could be calculated based on the relative fractions of microalgae and sewage sludge, and their methane productions. The values obtained in this way were slightly higher than the calculated productions; however, the differences were less than $5 \%$, being not statistically significant to suggest synergy. All the substrates were similarly degraded and the methane production by the 7 th day had exceeded $80 \%$ of the ultimate methane production. These results are in agreement with the reported for other microalgae species and sewage sludge [23].

The C:N during N. oculata digestion was 5.36, far from the range 20 25 considered as optimal for $\mathrm{AD}[18,19,22]$. The $\mathrm{C}: \mathrm{N}$ in sewage sludge was 13.88 , thus the addition of sewage sludge did not increase the $C: N$ significantly. The synergistic effects observed during the Aco-D of microalgae and sewage sludge or other co-substrates have been attributed to the nutrients provided to microorganisms, more than to the $\mathrm{C}: \mathrm{N}$ balance $[19,22]$. Regarding the Aco-D of Nannochloropsis species, the synergetic effects were also attributed to the essential elements supply or an enhanced alkalinity [18]. In the present experiments, the addition 


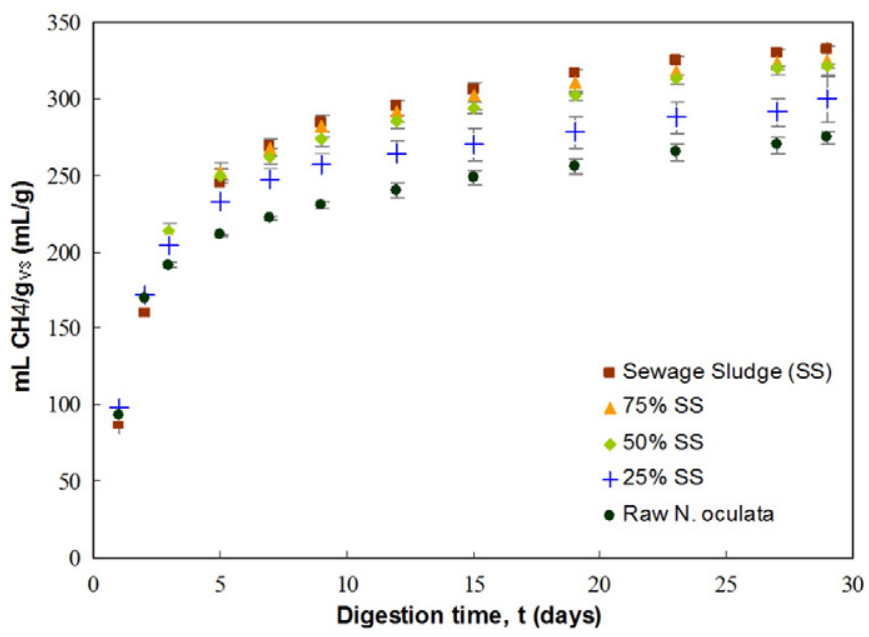

Fig. 4. The methane production curves from sewage sludge and $N$. oculata co-digestion. Symbols: raw microalgae, $+25 \%$ sewage sludge $50 \%$ sewage sludge, $\boldsymbol{\Delta} 75 \%$ sewage sludge and 100\% sewage sludge. Batch reactors at $33{ }^{\circ} \mathrm{C}$ and SIR of $1: 2$ $\mathrm{VS}_{\text {Substrate }}: \mathrm{VS}_{\text {Inoculum }}$

of synthetic medium containing micronutrients, vitamins and trace metals [26] may hide the benefits of the Aco-D. The lack of synergy may be also a consequence of the microalgae characteristics $[22,23]$.

In spite of the results mentioned above, the absence of inhibitory effects during Aco-D is favourable for a possible the integration of phycoremediation and anaerobic digestion. The integration of processes, growing microalgae for wastewater treatment and energy production, can be economically and environmentally beneficial $[10,19,22]$. The results demonstrate that this integration may be possible. Nannochloropsis species can consume nutrients from wastewaters during growth [5,35]; furthermore, digesters in WWTP are over-sized, being the non-used capacity approximately $30 \%$ [20].

\section{Conclusions}

The SIR reveals that AD of $N$. oculata can present inhibition if this ratio is higher than $1: 1$. The SIR 1:1 causes stress in the digesters, decreasing the $\mathrm{k}_{\mathrm{h}}$, but does not affect the ultimate methane production. On the contrary, the SIR does not affect $C$. vulgaris AD as consequence of the presence of aggregates in the biomass.

Although the pre-treatment with both solvents increases $N$. oculata biodegradability, only the pre-treatment using hexane increases the methane production. On the other hand, $C$. vulgaris requires stronger pre-treatment methods. The polar solvent increases the lipid and the biodiesel yields from both species, but does not affect the biodiesel composition.

Regarding Aco-D, the $\mathrm{C}: \mathrm{N}$ increase in the reactors does not affect the methane production. However, the absence of inhibitory effects suggests that $N$. oculata and sewage sludge could be digested in the same reactor.

\section{Acknowledgements}

Martín Pablo Caporgno thanks the Spanish Ministerio de Educación, Cultura y Deporte for his pre-doctoral scholarship (Ref. AP2012-3726). Financial support for this research was provided by the Spanish Ministerio de Educación y Ciencia and FEDER, project CTM201123069. This research was supported by the French National Research Agency project DIESALG (ANR-12-BIME-0001-02). The authors thank Gestió Ambiental i Abastament S.A. Company (WWTP of Reus, Spain) for their kind collaboration during this project.

\section{References}

[1] I. Rawat, R.R. Kumar, T. Mutanda, F. Bux, Biodiesel from microalgae: a critical evaluation from laboratory to large scale production, Appl. Energy 103 (2013) 444-467.

[2] A.J. Ward, D.M. Lewis, B. Green, Anaerobic digestion of algae biomass: a review, Algal Res. 5 (2014) 204-214.

[3] P. Bohutskyi, M.J. Betenbaugh, E.J. Bouwer, The effects of alternative pretreatment strategies on anaerobic digestion and methane production from different algal strains, Bioresour. Technol. 155 (2014) 366-372.

[4] L. Zhu, E. Hiltunen, Q. Shu, W. Zhou, Z. Li, Z. Wang, Biodiesel production from algae cultivated in winter with artificial wastewater through $\mathrm{pH}$ regulation by acetic acid, Appl. Energy 128 (2014) 103-110.

[5] M.P. Caporgno, A. Taleb, M. Olkiewicz, J. Font, J. Pruvost, J. Legrand, C. Bengoa, Microalgae cultivation in urban wastewater: nutrient removal and biomass production for biodiesel and methane, Algal Res. 10 (2015) 232-239.

[6] M.E. Montingelli, S. Tedesco, A.G. Olabi, Biogas production from algal biomass: a review, Renew. Sust. Energ. Rev. 43 (2015) 961-972.

[7] M. Olkiewicz, M.P. Caporgno, J. Font, J. Legrand, O. Lepine, N.V. Plechkova, J. Pruvost, K.R. Seddon, C. Bengoa, A novel recovery process for lipids from microalgae for biodiesel production using a hydrated phosphonium ionic liquid, Green Chem. 153 (2015) 118-125.

[8] J.J. Milledge, S. Heaven, Methods of energy extraction from microalgal biomass: a review, Environ. Sci. Technol. 13 (2014) 301-320.

[9] L. Lardon, A. Hélias, B. Sialve, J.P. Steyer, O. Bernard, Life-cycle assessment of biodiesel production from microalgae, Environ. Sci. Technol. 43 (2009) 6475-6481.

[10] S.K. Prajapati, P. Kumar, A. Malik, V.K. Vijay, Bioconversion of algae to methane and subsequent utilization of digestate for algae cultivation: a closed loop bioenergy generation process, Bioresour. Technol. 158 (2014) 174-180.

[11] P. Choudhary, A. Bhattacharya, S.K. Prajapati, P. Kaushik, A. Malik, Phycoremediationcoupled biomethanation of microalgal biomass, Handbook of Marine Microalgae (2015) http://dx.doi.org/10.1016/B978-0-12-800776-1.00032-7.

[12] M.E. Alzate, R. Muñoz, F. Rogalla, F. Fdz-Polanco, S.I. Pérez-Elvira, Biochemical methane potential of microalgae biomass after lipid extraction, Chem. Eng. J. 243 (2014) 405-410.

[13] P. Keymer, I. Ruffell, S. Pratt, P. Lant, High pressure thermal hydrolysis as pretreatment to increase the methane yield during anaerobic digestion of microalgae, Bioresour. Technol. 131 (2013) 128-133.

[14] B. Zhao, J. Ma, Q. Zhao, L. Laurens, E. Jarvis, S. Chen, C. Frear, Efficient anaerobic digestion of whole microalgae and lipid-extracted microalgae residues for methane energy production, Bioresour. Technol. 161 (2014) 423-430.

[15] E. Ryckebosch, C. Bruneel, R. Termote-Verhalle, K. Muylaert, I. Foubert, Influence of extraction solvent system on extractability of lipid components from different microalgae species, Algal Res. 3 (2014) 36-43.

[16] R.K. Balasubramanian, T.T. Yen Doan, J.P. Obbard, Factors affecting cellular lipid extraction from marine microalgae, Chem. Eng. J. 215-216 (2013) 929-936.

[17] M.P. Caporgno, C. Bengoa, Anaerobic digestion of microalgae: the benefits of digesting microalgae waste, Curr. Biochem. Eng. (2015) (in press).

[18] S. Schwede, A. Kowalczyk, M. Gerber, R. Span, Anaerobic co-digestion of the marine microalga Nannochloropsis salina with energy crops, Bioresour. Technol. 148 (2013) 428-435.

[19] S.K. Prajapati, P. Choudhary, A. Malik, V.K. Vijay, Algae mediated treatment and bioenergy generation process for handling liquid and solid waste from dairy cattle farm, Bioresour. Technol. 167 (2014) 260-268.

[20] J. Mata-Alvarez, J. Dosta, M.S. Romero-Güiza, X. Fonoll, M. Peces, S. Astals, A critical review on anaerobic co-digestion achievements between 2010 and 2013, Renew. Sust. Energ. Rev. 36 (2014) 412-427.

[21] M. Wang, A.K. Sahu, B. Rusten, C. Park, Anaerobic co-digestion of microalgae Chlorella sp. and waste activated sludge, Bioresour. Technol. 142 (2013) 585-590.

[22] J. Olsson, X.M. Feng, J. Ascue, F.G. Gentili, M.A. Shabiimam, E. Nehrenheim, E. Thorin, Co-digestion of cultivated microalgae and sewage sludge from municipal waste water treatment, Bioresour. Technol. 171 (2014) 203-210.

[23] M.P. Caporgno, R. Trobajo, N. Caiola, C. Ibáñez, A. Fabregat, C. Bengoa, Biogas production from sewage sludge and microalgae co-digestion under mesophilic and thermophilic conditions, Renew. Energy 75 (2015) 374-380.

[24] M.E. Alzate, R. Muñoz, F. Rogalla, F. Fdz-Polanco, S.I. Pérez-Elvira, Biochemical methane potential of microalgae: influence of substrate to inoculum ratio, biomass concentration and pre-treatment, Bioresour. Technol. 123 (2012) 488-494.

[25] M. Olkiewicz, M.P. Caporgno, A. Fortuny, F. Stüber, A. Fabregat, J. Font, C. Bengoa, Direct liquid-liquid extraction of lipid from municipal sewage sludge for biodiesel production, Fuel Process. Technol. 128 (2014) 331-338.

[26] I. Angelidaki, W. Sanders, Assessment of the anaerobic biodegradability of macropollutants, Rev. Environ. Sci. Biotechnol. 3 (2004) 117-129.

[27] E.W. Rice, R.B. Baird, A.D. Eaton, L.S. Clesceri, Standard Methods for the Examination of Water and Wastewater, 22nd ed. APHA, AWWA, WEF, 2012.

[28] S.K. Prajapati, A. Malik, V.K. Vijay, Comparative evaluation of biomass production and bioenergy generation potential of Chlorella spp. through anaerobic digestion, Appl. Energy 114 (2014) 790-797.

[29] E.A. Ehimen, S. Connaughton, Z. Sun, G.C. Carrington, Energy recovery from lipid extracted, transesterified and glycerol codigested microalgae biomass, Glob. Chang. Biol. Bioenerg. 1 (2009) 371-381.

[30] M.A. Pistorius, W.J. DeGrip, T.A. Egorova-Zachernyuk, Monitoring of biomass composition from microbiological sources by means of FT-IR spectroscopy, Biotechnol. Bioeng. 103 (2008) 123-129.

[31] G. Knothe, "Designer" biodiesel: optimizing fatty ester composition to improve fuel properties, Energy Fuel 22 (2008) 1358-1364. 
[32] A. Converti, A.A. Casazza, E.Y. Ortiz, P. Perego, M. Del Borghi, Effect of temperature and nitrogen concentration on the growth and lipid content of Nannochloropsis oculata and Chlorella vulgaris for biodiesel production, Chem. Eng. Process. 48 (2009) 1146-1151.

[33] J.H. Mussgnug, V. Klassen, A. Schlüter, O. Kruse, Microalgae as substrates for fermentative biogas production in a combined biorefinery concept, J. Biotechnol. 150 (2010) 51-56.
[34] P. Bohutskyi, B. Ketter, S. Chow, K.J. Adams, M.J. Betenbaugh, F.C.T. Allnutt, E.J Bouwer, Anaerobic digestion of lipid-extracted Auxenochlorella protothecoides biomass for methane generation and nutrient recovery, Bioresour. Technol. 183 (2015) 229-239.

[35] L. Jiang, S. Luo, X. Fan, Z. Yang, R. Guo, Biomass and lipid production of marine microalgae using municipal wastewater and high concentration of $\mathrm{CO}_{2}$, Appl. Energy 88 (2011) 3336-3341. 